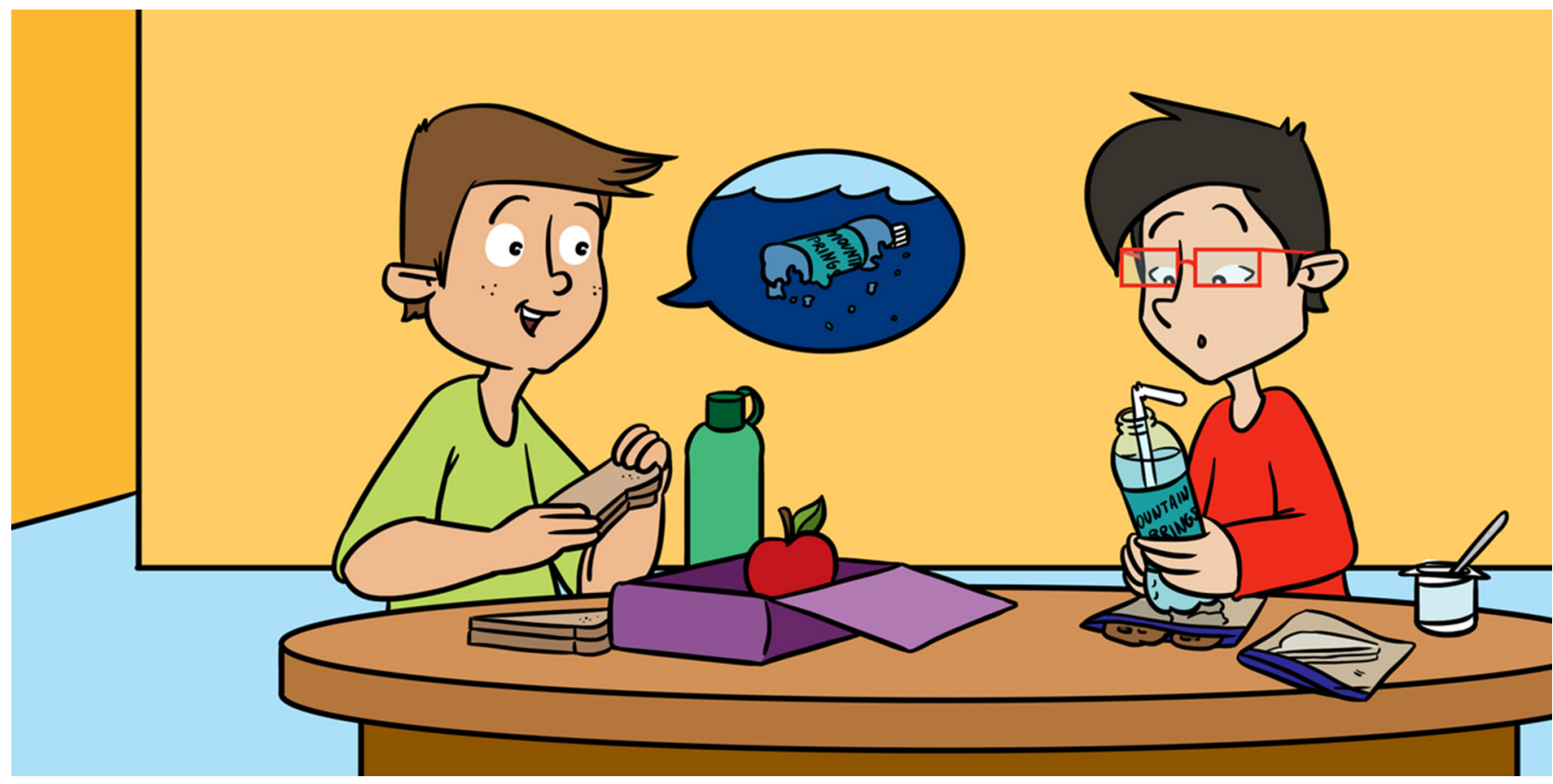

\title{
HOW ARE MICROPLASTICS INVADING THE WORLD?
}

Charlene Lujan-Vega ${ }^{1,2^{*}}$, José Luis Ortega-Alfaro ${ }^{2,3}$, Jennifer Cossaboon $^{1}$, Shawn Acuña ${ }^{4}$ and Swee J. $\operatorname{Teh}^{1}$

${ }^{1}$ Aquatic Health Program, School of Veterinary Medicine, University of California, Davis, Davis, CA, United States

${ }^{2}$ Microplastic Fauna Peru Project, Lima, Peru

${ }^{3}$ Laboratory of Ecology and Animal Biodiversity, Universidad Nacional Federico Villarreal, Lima, Peru

${ }^{4}$ Metropolitan Water District of Southern California, Sacramento, CA, United States

YOUNG REVIEWERS:

CORTE

MADERA

SCHOOL

AGES: $10-11$
Microplastics are tiny plastic pieces, $<5 \mathrm{~mm}$, which is smaller than a pencil eraser. Did you know that you can find microplastics everywhere? They are in the air, water, soil, and within living creatures. You can find them from the deep sea to the snow in the Arctic. You can find them across beaches in California, and in the San Francisco Bay waters. Many living organisms ranging from zooplankton to whales contain microplastics in their bodies, including aquatic creatures from California. In this article, you will learn about the origin of microplastics, where you can find them, why they are a concern, how they can affect the Sacramento-San Joaquin Delta, and how you can help to reduce their global invasion.

\section{WHAT ARE MICROPLASTICS AND HOW DO THEY ORIGINATE?}

Microplastics are little plastic pieces $<5$ millimeters $(\mathrm{mm})$, or about $1 / 5$ inch, in size. Depending on their origin, these plastic pieces can be 
Figure 1

Microplastics suspended in water. Microplastics can be classified as (A) primary microplastics, which are created as small particles and used to create larger plastic objects or in personal care products like toothpastes, or (B) secondary microplastics, which result from the breakdown of larger plastic objects, such as a plastic bottle. Microplastics can exist as (C) pellets, (D) fragments, (E) fibers, (F) foams, (G) films, or (H) granules. Some microplastics can act as fomites, transporting (I) hazardous chemicals, or (J) pathogens.

\section{PRIMARY}

\section{MICROPLASTICS}

Microplastics originally manufactured as tiny particles for industrial use such as microbeads in personal care products, or microfibers in synthetic textiles.

\section{SECONDARY MICROPLASTICS}

Microplastics formed overtime from the breakdown of large plastic pieces in the environment.

\section{FOMITES}

Inanimate objects that transport disease-causing pathogens such as viruses and bacteria.

\section{PATHOGENS}

Tiny agents of disease, such as viruses, bacteria, and parasites.

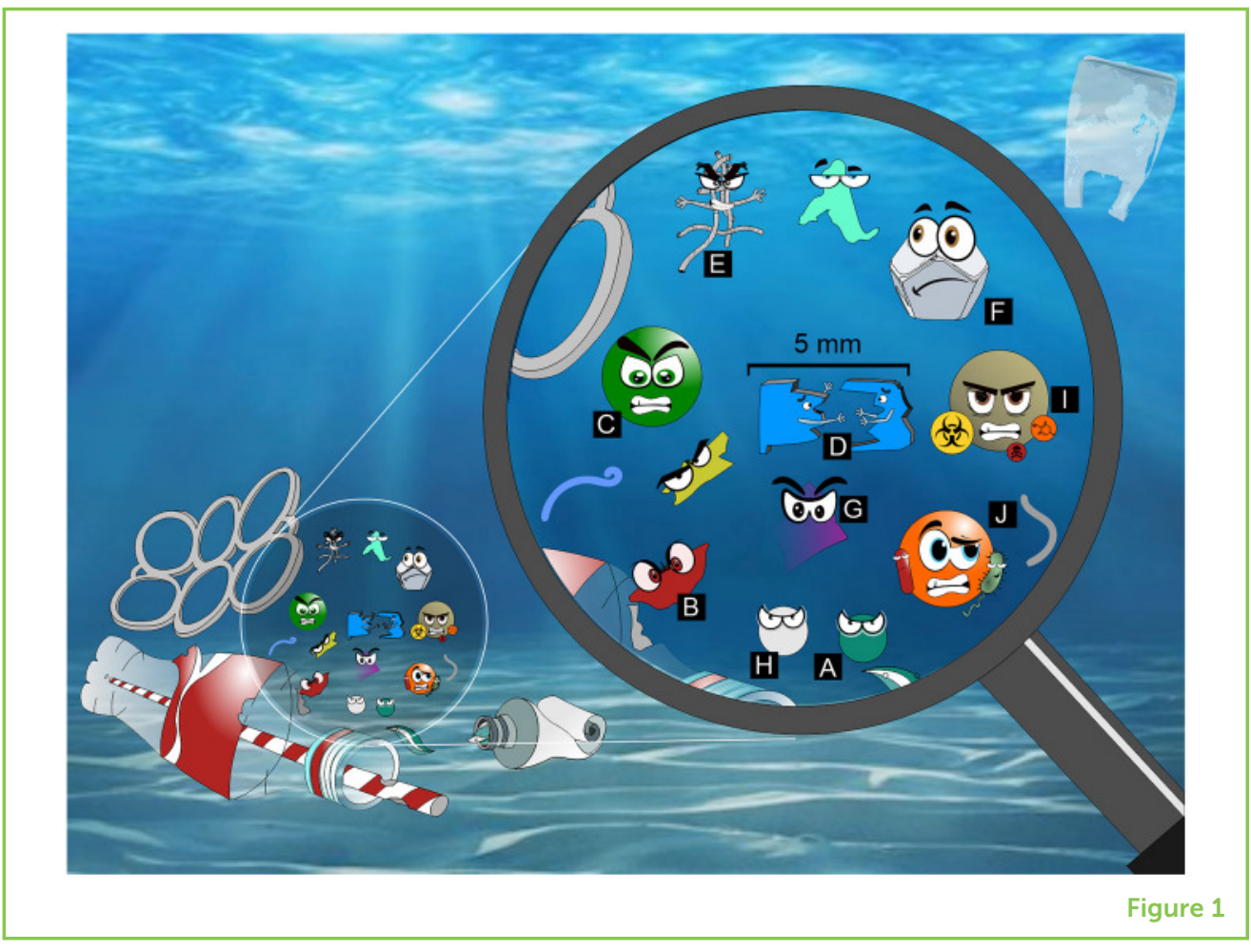

considered primary or secondary microplastics. Primary microplastics are originally manufactured as this tiny size for industrial use. For example, plastic microbeads are used in personal care products, like toothpastes and skin creams. Secondary microplastics originate from the fragmentation of larger plastic materials, such as plastic bottles, bags, straws, and containers, which break down in the environment over time to become microplastics (Figures 1A,B).

When classified by their visual appearance, microplastics can be pellets, fragments, fibers, foams, films, or granules (Figures $1 \mathrm{C}-\mathrm{H}$ ). Pellets are manufactured as little spheres to produce bigger plastic items, whereas fragments originate from plastic bottles or other plastic items that break down over time. Fibers typically come from synthetic clothes, while foam usually comes from single-use Styrofoam containers. Films enter the environment from plastic bags or food packaging, and granules come from personal care products like toothpaste. Pellets and granules are both are round, but pellets are much larger.

\section{WHY ARE MICROPLASTICS A CONCERN?}

Microplastics are a growing environmental concern because they can act as fomites for chemicals and disease-causing organisms called pathogens (Figures $11, J)[1,2]$. This means that dangerous chemicals and harmful germs can use microplastics to hitchhike through the environment. Microplastics are also a concern because they are so 


\section{ZOOPLANKTON}

Small, animal-like organisms that inhabit aquatic environments.

\section{ECOSYSTEM}

A system of interactions between living organisms and their environment.

\section{BIOTA}

The living organisms (plants and animals) of a specific ecosystem. tiny and often look like food, so they can be eaten by aquatic and marine animals of all sizes. Zooplankton, little organisms living in aquatic environments that mainly eat tiny algae, will eat less food after ingesting microplastics [3]. Microplastics can become entangled within the zooplankton gut and lead to starvation, a state in which the animal no longer gets enough energy from food to survive. On a much larger scale, whales that eat massive amounts of plankton end up filtering out and consuming these microplastics, some of which carry toxic chemicals. Both the microplastics and the chemicals can accumulate in their bodies [4]. Thus, microplastics have multiple ways of harming the health of many marine animal species.

\section{WHERE ARE MICROPLASTICS AND HOW CAN THEY AFFECT THE SACRAMENTO-SAN JOAQUIN DELTA?}

Microplastics are everywhere around the world! They have made it into all the environmental compartments of an ecosystem: air, soil, water, and biota (living organisms) (Figure 2). For instance, synthetic microfibers (manmade fibers that come primarily from clothing) have been found in water, on beaches, and even in air [5, 6]. A study in the San Francisco Bay found that there are more than 1 million microplastic particles per square mile of surface water [5]. This is the same as finding over 300 microplastic pieces on a credit card-sized area! Moreover, microplastics (consisting mainly of microfibers) were found everywhere across California beaches, from Marin County in the San Francisco Bay to more than 560 miles away in San Diego, the southernmost county in California [6]. Biota of the San Francisco Bay can contain and generate microplastics, too. Pacific mole crabs and mussels accumulate microplastics in their bodies, while other marine crustaceans can generate microplastics by digging in big blocks of foam [6-8].

The Sacramento-San Joaquin Delta is a unique ecosystem where freshwater mixes with seawater, generating conditions that support diverse animal, plant, and insect species. Furthermore, the Delta serves as an important source of drinking water and agriculture for millions of people in California. The conservation of this valuable ecosystem is everyone's responsibility. San Francisco Bay area is to the west of the Sacramento-San Joaquin Delta. Higher concentrations of microplastics have been found in the San Francisco Bay waters than in the waters around other urban areas of the United States [5], and further studies are currently in progress in the Delta. Microplastic contamination in the Delta appears inevitable. There is also contamination from pesticides and other environmental contaminants that can combine to affect the health of the organisms living there. Around the world, microplastics have been found in drinking water (see Video) and fish. However, are there microplastics in California drinking water? Do people consume fish with microplastics in them? Do microplastics affect human health? These are some 
Figure 2

Microplastics in the four environmental compartments of a freshwater ecosystem: air contains floating synthetic microfibers: soil contains diverse microplastics and plastic debris; water contains suspended microplastics that interact with chemicals, bacteria, sediment, and living organisms; and biota such as fish contain microplastics in their guts.

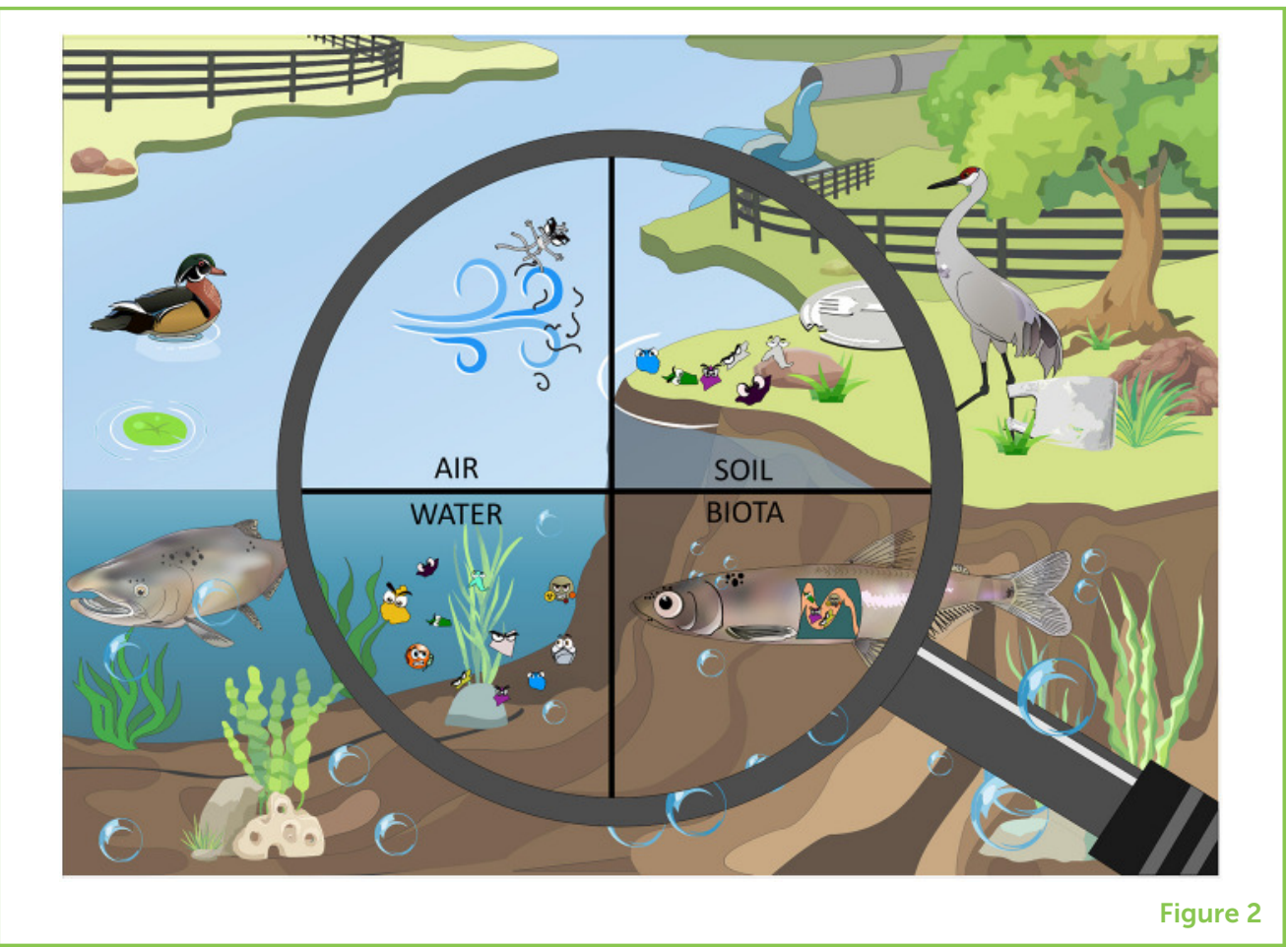

important questions that are still unsolved in the Sacramento-San Joaquin Delta region.

\section{WHAT CAN WE DO TO FIGHT THIS INVASION?}

Did you know that, in 2017, only about $8 \%$ of plastic in the United States was recycled, and almost 27 million tons of plastic were added to landfills? As it breaks down over time, all this plastic will become secondary microplastics. Can you imagine how many tons of microplastics will be generated on Earth over the next 10 years? Remember that 27 million tons is only the plastic waste from one country in one year. Just imagine how much plastic trash we generate worldwide! This plastic overuse comes primarily from our reliance on single-use plastic products, including plastic bags, straws, plastic bottles, and foam containers.

One possible solution is to redesign the plastic industry to use new types of plastic or alternative materials that will not harm the environment. Another helpful action is to ban single-use plastics and personal-care products containing microbeads. In San Francisco, California, single-use plastic bags have been banned in grocery stores. However, these actions are not enough. Eliminating all single-use plastics will take a lot of time and effort. Many scientists are already working on alternative materials, but you can help with your own ideas, too. We invite you to brainstorm creative solutions with your science teachers and friends, by playing, experimenting, and testing. 
There are other ways that you can prevent the current environmental invasion of microplastics. For example, you can avoid the unnecessary use of plastics in your daily life. Do you bring your sandwich to school in a plastic bag every day or drink water from single-use plastic bottles? Replace these with reusable containers. Do you use toothpaste with microbeads? Check the ingredients and use the internet to choose brands that do not contain microplastics. Do you use plastic straws to drink your soda? Choose a biodegradable straw or better yet, do not use one at all! You have the power to make choices that help the planet. You can also help limit the microplastic invasion by spreading the word and telling your friends and family why microplastics are a global concern. It is important that as many people as possible raise awareness of the danger that microplastics pose for our planet, and now you know enough to help with this mission!

\section{ACKNOWLEDGMENTS}

CL-V studies were supported by the fellowship Beca Doctorado en el Extranjero, contract $\mathrm{N}^{\circ}$ 236-2018, FONDECYT from the Peruvian Government.

\section{REFERENCES}

1. Gallo, F., Fossi, C., Weber, R., Santillo, D, Sousa, J., Ingram, I., et al. 2018. Marine litter plastics and microplastics and their toxic chemicals components: the need for urgent preventive measures. Environ Sci Eur. 30:13. doi: 10.1186/s12302-018-0139-z

2. Kirstein, I. V., Kirmizi, S., Wichels, A., Garin-Fernandez, A., Erler, R., Löder, M., et al. 2016. Dangerous hitchhikers? Evidence for potentially pathogenic Vibrio spp. on microplastic particles. Mar Environ Res. 120:1-8. doi: 10.1016/j.marenvres.2016.07.004

3. Cole, M., Lindeque, P., Fileman, E., Halsband, C., Goodhead, R., Moger, J., et al. 2013. Microplastic ingestion by zooplankton. Environ Sci Technol. 47:6646-55. doi: 10.1021/es400663f

4. Fossi, M. C., Panti, C., Guerranti, C., Coppola, D., Giannetti, M., Marsili, L., et al. 2012. Are baleen whales exposed to the threat of microplastics? A case study of the Mediterranean fin whale (Balaenoptera physalus). Mar Pollut Bull. 64:2374-9. doi: 10.1016/j.marpolbul.2012.08.013

5. Sutton, R., Mason, S. A., Stanek, S. K., Willis-Norton, E., Wren, I. F., and Box, C. 2016. Microplastic contamination in the San Francisco Bay, California, USA. Mar Pollut Bull. 109:230-5. doi: 10.1016/j.marpolbul.2016.05.077

6. Horn, D., Miller, M., Anderson, S., and Steele, C. 2019. Microplastics are ubiquitous on California beaches and enter the coastal food web through consumption by Pacific mole crabs. Mar Pollut Bull. 139:231-7. doi: 10.1016/j.marpolbul.2018.12.039

7. Klasios, N., De Frond, H., Miller, E., Sedlak, M., and Rochman, C. M. 2021. Microplastics and other anthropogenic particles are prevalent in mussels from 
San Francisco Bay, and show no correlation with PAHs. Environ Pollut. 271:116260. doi: 10.1016/j.envpol.2020.116260

8. Davidson, T. M. 2012. Boring crustaceans damage polystyrene floats under docks polluting marine waters with microplastic. Mar Pollut Bull. 64:1821-8. doi: 10.1016/j.marpolbul.2012.06.005

SUBMITTED: 16 September 2020; ACCEPTED: 28 September 2021; PUBLISHED ONLINE: 25 October 2021.

EDITED BY: Peggy W. Lehman, California Department of Water Resources, United States

CITATION: Lujan-Vega C, Ortega-Alfaro JL, Cossaboon J, Acuña S and Teh SJ (2021) How Are Microplastics Invading the World? Front. Young Minds 9:606974. doi: 10.3389/frym.2021.606974

CONFLICT OF INTEREST: The authors declare that the research was conducted in the absence of any commercial or financial relationships that could be construed as a potential conflict of interest.

COPYRIGHT @ 2021 Lujan-Vega, Ortega-Alfaro, Cossaboon, Acuña and Teh. This is an open-access article distributed under the terms of the Creative Commons Attribution License (CC BY). The use, distribution or reproduction in other forums is permitted, provided the original author(s) and the copyright owner(s) are credited and that the original publication in this journal is cited, in accordance with accepted academic practice. No use, distribution or reproduction is permitted which does not comply with these terms.

\section{YOUNG REVIEWERS}

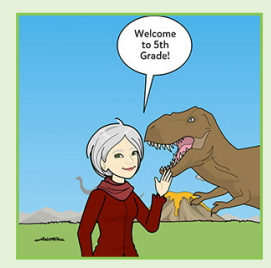

\section{CORTE MADERA SCHOOL, AGES: 10-11}

We are a fifth grade class, excited about all things science. Since we live in the San Francisco Bay Area, we love to learn about the amazing wildlife and the natural environment around us.

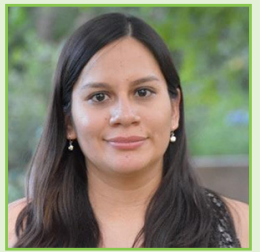

\section{AUTHORS}

\section{CHARLENE LUJAN-VEGA}

I am a veterinarian from Peru and currently a pharmacology and toxicology Ph.D. student researcher in the Aquatic Health Program at the University of California, Davis. I have been always passionate about understanding the diseases of wild birds. My research focuses on how microplastics and their associated contaminants can harm seabirds from the Humboldt Current Ecosystem in Peru. My second passion is teaching. I developed a research volunteer program at Microplastic Fauna Peru Project for a group of young Peruvian researchers. *cmlujanvega@gmail.com 


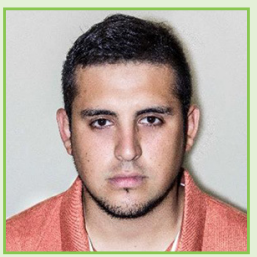

\section{JOSÉ LUIS ORTEGA-ALFARO}

I recently graduated with a bachelor's degree in biology from the Universidad Nacional Federico Villarreal in Lima, Peru. Currently, I am an ecotoxicology researcher at the Laboratory of Ecology and Animal Biodiversity and the research coordinator at Microplastic Fauna Peru Project, where I am studying the tissue distribution of microplastics in fish species from various trophic levels of the Humboldt Current Ecosystem in Peru. I would like to contribute to the understanding of toxic compound dynamics and to propose alternatives and solutions to human-made pollution.
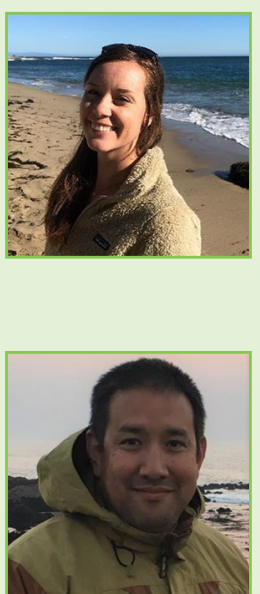

\section{JENNIFER COSSABOON}

I am a doctoral student researcher in the Aquatic Health Program at the University of California, Davis. My fascination with wildlife health and toxicology began while working with seals and sea lions in Monterey Bay and Alaska. I am now pursuing a D.V.M/Ph.D., to pair research tools with clinical skills, so I can continue researching the role of contaminants in animal and human diseases.

\section{SHAWN ACUÑA}

Shawn Acuña is a senior resource specialist for the Metropolitan Water District of Southern California. He has almost 20 years of experience in the field of fish biology and environmental science. He has a B.S. in aquatic biology from U.C. Santa Barbara and an M.S. in animal biology and a Ph.D., in ecology from U.C. Davis. He has expertise in gross pathology, histopathology, and nutrition and health biomarkers, and has conducted field and laboratory studies on environmental stressors. He currently works on stressors and stressor effects in the San Francisco Estuary, to help keep the Estuary healthy.

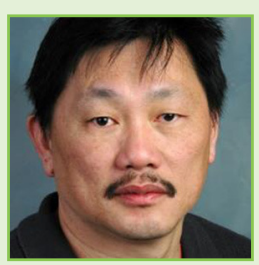

\section{SWEE J. TEH}

Swee Teh, Ph.D., is the director of the Aquatic Health Program in the School of Veterinary Medicine at the University of California, Davis, and the director of the Aquatic Toxicology Laboratory; a state- certified laboratory engaged in monitoring and assessing water quality and aquatic ecosystem health. He has published over 100 research articles in peer-reviewed journals. He researches the effects and interactions of various water contaminants on aquatic organisms and ecosystems. He has been married to his wife Foo-Ching for 39 years. They have two grown children who currently live in California. 